\title{
The Influence of Sustainability Disclosure on Firm Value's with Board Involvement as A Moderating Variable: Evidence from Indonesia
}

\author{
Januarti Tiurmaida $^{1}$ Yvonne Augustine S. ${ }^{2 *}$ \\ 1. School of Economics, Trisakti University, Phone: (62-21) 566 3232, Jakarta, Indonesia \\ 2. School of Economics, Trisakti University, Phone: (62-21) 566 3232, Jakarta, Indonesia
}

\begin{abstract}
The objective of this research was to find out the effects of the disclosure of Sustainability Reporting including the economic performance disclosure, environmental performance disclosure and social performance disclosure, and also the board involvement on the firm value. Sustainability disclosure is the company's effort to make the company accountable for all stakeholders, for the company's performance goals towards sustainable development. The population of the research was the companies listed in the Indonesia Stock Exchange for the period of 2015 2017. This research uses the content analysis method, namely the quantitative research, to find out the relationship between one independent variable (sustainability disclosure, covers economic, environmental and social performance disclosure) and the dependent variable (company performance) with the board involvement as the moderating variable.

The results of the research indicated that the board involvement moderated the disclosures of economic, environmental and social performance towards the value of the company. Further research indicated that the disclosure of Sustainability Reporting that included the economic, environmental, and social performance disclosure, had significant effect to the company value, but it is negative. The negative value shows that the cost spent for the disclosure of the Sustainability Reporting is still greater than its effect towards of the firm value.
\end{abstract}

Keywords: Sustainability Disclosure, Economic Performance, Environmental Performance, Social Performance, Board Involvement, Company Performance, and Content Analysis.

DOI: $10.7176 / \mathrm{JESD} / 10-10-21$

Publication date:May $31^{\text {st }} 2019$

\section{Introduction}

Environment cannot be separated from life. As an environment, earth is the home of human and serves as a place for human to carry out their various activities. If the environment is damaged or the resources are depleted due to the human's greed then the one who will lose is the human themselves. That is the importance reason for human not to destroy their nature, and carry out the development by taking into account the sustainability of its natural resources. The main reason for the importance of the sustainable development is because the number of people has been exceeded the ideal capacity of the inhabitants of the earth since decades ago.

Because natural resources must actually be able to be used up by the next generation, it is necessary to make the natural resources be used as efficiently as possible and their added value is increased as well, then how all these activities form a recycling process so that everything can be utilized. Also there needs to be harmonization in all levels of society and government intervention in the economic processes which are of course related to the process of sustainable development so that the exploitation of the natural resource does not occur or harm certain parties.

Furthermore, along with the course of time, people demanded the company to provide social responsibility, then the company developed the 3P concept, namely People, Planet and Profit well-known as the Triple Bottom-Line concept Elkington 1997). According to Elkington, if a company wants to maintain its survival, the company must care about the "3P", that is in addition to benefit, the company must also pay attention to and be involved in fulfilling people's welfare and actively contributing to the preservation of the environment. The concept is the reflection of the terminology known by various companies in the world, namely Sustain Ability which has its own meaning for the company, that is the company's ability to survive as long as possible or is called the Long-Life Company.

Nowadays many companies in the world are required to provide accountability reports to their stakeholders. The stakeholders are interested to know whether the company's approach and performance are sustainable in various aspects, especially economic, environmental and social aspects, including the potential to create company value 
through sustainable management. Until now, the implementation of sustainability is still voluntary, so there is a tendency for many companies to ignore the implementation of sustainability development. Regarding the company's ignorance to make this report, it can be caused by several reasons, such as additional costs and the effort in making the reports. In addition, with the absence of the obligation from the capital market regulators regarding this reporting, companies listed on the Indonesia Stock Exchange tend to think that they did not need to prepare related reports. But the government seeks any ways to encourage the implementation of sustainability development through the Indonesia Sustainability Reporting Award (ISRA).

The objective of companies is to use sustainability reports, one of which is to manage relationships with their stakeholders. By doing this, the companies prove that they really take the sustainability for the future into account. Besides, this gives additional value to the company because of the company's voluntary reports so that it can increase the investors' confidence in investing their funds to the company. Moreover, the disclosure of the sustainability report will then build confidence among the consumers, suppliers as well as investors towards the company and hopefully it will promote the consumers, suppliers and investors' interest to buy the products from the companies, which will then indirectly have an impact on increasing the operational activities run by the company and on the corporate value as well (Ernst and Young 2012).

In relation to the stakeholders' interests, one of the tasks of the management of a company is to improve what is called shareholders value for the shareholders. The measurement of company value mostly used is Tobins Q, which is calculated by comparing the closing price multiplied by the number of shares, added by the total liabilities and inventory, subtracted by the current asset and then divided by the total assets. For investors, the value of the company can serve as a description of the company being planned for investment.

Several previous studies have been carried out to examine the effects of disclosure of the Sustainability Report, along with the performance aspects contained in the performance of companies outside Indonesia, among others which state that there is a positive relationship between sustainability disclosure and company performance (Bodhanwala and Bodhanwala 2018). The results of other studies suggest that there is a positive relationship between the sustainability of company performance and performance (Yu and Zhao 2015) and states that the adoption of sustainability and corporate governance influences company performance (Chong, Ong and Tan 2018).

The implementation of sustainability reporting that requires management support, can be in form of the involvement of company management that encourages the disclosure of sustainability activities in corporate reporting. Limited Liability Companies as legal entities in carrying out the management of Limited Liability Companies have organs, including directors and commissioners (Law number 40 of 2007). The Board of Directors is the organ of the company which has the authority and is fully responsible for the management of the Company, for the benefit of the Company in accordance with the purposes and objectives of the company, and representing the Company, both inside and outside the court in accordance with the provisions of the Articles of Association (Law number 40 of 2007). Whereas commissioners are the organ of the company whose job it is to exercise control as regulated in the articles of association and provide advice to the Directors.

The results of some research indicate that the involvement of directors or "boards" has an effect on sustainability disclosure by the board structure in a company (Mudiyanselage 2018). The board includes the size of directors and the more female directors structure (Mudiyanselage 2018). Furthermore, the other results also stated that sustainability disclosures are influenced by the board structure in a company. The board structure that influences the sustainability disclosures is the size of the board (Shamil et al. 2014).

In some of the studies mentioned above, board involvement refers to the involvement of directors, but in this research, what is meant by board involvement is the involvement of the board of commissioners in company management with the consideration that Indonesia uses a two-level system in managing the company (Law No. number 40 years 2007 concerning Limited Liability Companies).

Based on the description of the background above, the author assumed that research needs to be done to see whether there is an influence of sustainability disclosure on the performance of companies in Indonesia.

\section{Literature Review dan Hipotesis}

The theory of stakeholder was initially built due to the awareness and understanding that companies have stakeholders, those who have interests in the company. The term stakeholder was first stated by the Stanford Research Institute (SRI), which is that groups without an organization's support will no longer exist (Freeman, 1983). The statement leads to the existence of an organization or company that will be greatly influenced by the support of groups that have a relationship with the organization. The company must maintain relationships with 
its stakeholders, especially stakeholders who have power over the availability of resources used for company operational activities, such as labor, markets (Ghozali et. al. 2013). Regarding the implementation of sustainability, the results of research show the importance of involving stakeholders in the entire process of accounting and sustainability reporting, developing strategic plans and sustainability indicators, measuring performance and preparing sustainability reports (Amanpreet Kaur and Sumit Lodhia 2018).

Stakeholder theory deals with the problem of managing resources or management (managerial) and recommends attitudes, structures, and practices that will shape the stakeholder management philosophy if applied together (Donaldson and Preston 1995). Furthermore, based on characteristics, stakeholders are classified into two, namely primary or primary stakeholders and secondary stakeholders (Clarkson 1995). The main stakeholders are one or a group without which the company cannot survive, among others: shareholders and investors, employees, consumers, suppliers, government and society. Secondary stakeholders are one or a group that is influenced or can be a company, but not related to the company's operational activities.

Legitimacy theory states that an organization or company will make efforts to ensure that the organization or company will carry out its operational activities in accordance with the norms in the community where the company carries out its operational activities. It aims to ensure that the operational activities carried out by an organization or company are accepted by the local community. Matters that form the basis of legitimacy theory, namely social contracts between companies and communities where companies operate and use economic resources (Ghozali et. al. 2013). Social contracts are all social institutions, without exception for companies, operating in society through social contracts, both explicitly and implicitly, where their survival and growth are based on socially available results for all members of society and economic, social or political distribution beneficial to groups according to their strengths (Shocker and Sethi, 1974). Legitimacy is a system-oriented view of organization and society, permits us to focus on the role of information and disclosure in the relationship between organizations, the state, individuals and group (Gray et al. 1996).

Sustainability development is a concept that aims at creating a balance of all dimensions of development, such as economy, social and environmental. Sustainability development is a process of developing things (city, business, land, community, etc.) with the principle of meeting current needs without compromising the fulfillment of the needs of future generations. According to the United Nations World Summit 2005, sustainability or sustainable development encompasses three policy spheres, which are interconnected one with each other and function as a driving force for the sustainability development. Kotler and Lee identified several choices of programs for companies to implement initiatives as well as activities related to various social problems and at the same time as a manifestation of the company's commitment on social responsibility.

Sustainability reports provide not only information relating to financial performance, but also non-financial performance. Non-financial information includes information on company activities, both social and environmental (Elkington 1997). Implementation of sustainability reports in Indonesia is supported by Government Regulations such as Law Number 40 of 2007 concerning Limited Liability Companies. The implementation of reporting the activities on social and environmental responsibility disclosed through sustainability report requires a guideline. One of the guidelines that can be used is the Global Reporting Initiative (GRI). In Indonesia, this guideline is used by The National Center for Sustainability Reporting (NCSR), as an independent institution which periodically provides assessments to the disclosures of sustainability report submitted by companies.

Sustainability Reporting provides information related to any material aspects that is the aspects reflecting the economic, environmental, and social impacts of the organization, as follows:

- The dimensions economic of sustainability which is related to the impact of the organization on the economic situation for its stakeholders, and on the economic system at the local level.

- The dimensions environment of sustainability that affect the organization include the environment in the form of living resources and non-living resources, including land, air, water, and ecosystems.

- The dimensions social of sustainability discusses the affect of the organization on the social system at which the organization operates. The dimensions of social sustainability contain sub-categories, namely employment practices and work convenience, human rights, society, and responsibility for the products.

In this research, company value is defined as market value, because the value of the company will be able to provide maximum welfare to shareholders if the company's stock price increases. Market value is formed by the demand and supply of shares by market participants. Company value is an important indicator for the market in assessing the company as a whole. The measurement of performance value in this research uses Tobins Q which 
is calculated by comparing the closing price multiplied by the number of shares, added by the total liabilities and inventory, subtracted by the current asset and then divided by the total assets. The results of a research showed that there was a positive relationship between sustainability performance and the firm value (Yu and Zhao 2015).

Board as the main internal managerial mechanism in a company has the power to decide on the company's mission and policies, and is responsible for safeguarding the interests of the company's stakeholders. Indonesia adheres to a two-tier system concept consisting of the General Meeting of Shareholders, the Board of Directors, and Executive Managers (Law Number 40 year 2007), while the one-tier system consists of GMS, Board of Commissioners, Directors, and Executive Managers. This structure separates the board membership, namely the membership of the board of commissioners as the supervisor and the board of directors as the company executive.

In this research, the nomenclature "board" includes the board of directors and the board of commissioners. Furthermore, in relation to sustainability disclosure, the board plays an important role, this is due to fact that up to the present, the sustainability disclosure is not mandatory for the company or is still voluntary. So that sustainability disclosure can be influenced by the board structure in a company (Mudiyanselage 2018).

\section{Development of Hypotheses}

Sustainability disclosure provides many benefits for the company and for the company's stakeholders themselves (World Business Council for Sustainable Development). The results of previous research show that between sustainability disclosure and company performance there is a positive relationship (Yu and Zhao, 2015). The aspects of sustainability disclosure in a sustainability reporting contains three aspects, including the assessment of economic, environmental and social performance (Global Reporting Initiative). The results of previous studies indicate that reports on the sustainability of economic, environmental and social disclosures have a significant correlation with firm value (Bartlett 2012). Likewise, the other research showed that companies which implemented sustainability development generally had positive correlation with the company profitability (Shernaz and Ruzbeh 2018). Based on this, the hypothesis that is built is:

H1 : There is a positive influence on economic performance disclosure towards the company performance

$\mathrm{H} 2$ : There is a positive influence on environment performance disclosure towards the company performance

H3 : There is a positive influence on social performance disclosure towards the company performance

In this research the author described the application of board involvement as a moderating variable that can moderate the relationship of sustainability disclosure. The results of previous studies showed that sustainability disclosures can be influenced by the board structure in a company (Mudiyanselage 2018 and Shamil et al. 2014). Based on this, the hypothesis that is built is:

H4 : Board involvement can moderate the influence of economic performance disclosure towards the company performance

H5 : Board involvement can moderate the influence of environment performance disclosure towards the company performance

H6 : Board involvement can moderate the influence of social performance disclosure towards the company performance

\section{Research Methodology}

The type of research used in this research is the quantitative research with causal or causative relationships that aims to analyze the causal relationship between variables (two or more), the independent and dependent ones, which influence and are influenced as suggested by Sugiyono (2014). The data in this research are in the form of quantitative data or secondary data sourced from reports from the Indonesia Stock Exchange in the form of annual reports (sustainability reports and financial statements) the period of 2015 to 2017. The population of this research are manufacturing companies listed on the Indonesia Stock Exchange. The choice of manufacturing companies as the population of the research is due to the fact that the manufacturing companies have relatively many impacts on the environment and society so they are able to cover the aspects of the research.

Content analysis is a technique of research for making inferences that can be replicated and validated by looking at the context (Krippendorff 1986). In the process to apply the content analysis, the measurement of sustainability disclosure performance which is carried out through annual reports, requires information guideline. The reference guideline to the Sustainability Disclosure report that currently dominates the research is the Global Reporting Initiative (GRI). The steps of processing in the content analysis (Gunawan and Abadi 2010) are (1) the process of 
checking or correcting collected data; (2) the process of giving codes to each data included in the same category; and (3) the scoring process using Likert scale -one of the ways to determine the score. For quantitative information, the score will range from 1 to 5 , and for qualitative information the score is from 1 to 8 .

This analysis is intended to put the data into groups based on the variables studied, tabulating the data based on variables obtained from all respondents. According to Robert and Yvonne (2018), the descriptive analysis is a statistic used to analyze data by describing the data that has been collected as it is without intending to make conclusions to be applied as a generalization. In general, the descriptive analysis is categorized into two, namely the size of the data concentration consisting of mean, median and mode, and the size of the data distribution consisting of range, variance, and standard deviation.

Furthermore, the classic assumption test includes (1) normality test, which is to see the residual value is normally distributed through histogram test, P plot normality test, Chi Square test, Skewness and Kurtosis or Kolmogorov Smirnov test; (2) multicollinearity test, namely to see whether there is a high correlation between independent variables in multiple linear regression models through Variance Inflation Factor, Pearson correlation test; (3) heteroscedasticity test, which is to see whether there are inequalities in variance from residuals to the other observations through the Glejser test, Park test or White test; and (4) autocorrelation test, which is to see whether there is a correlation between a period $t$ and the previous period $(\mathrm{t}-1)$ and is done on the time series data or at the sequential time.

After the classical assumption test is fulfilled, then multiple linear regression tests are carried out is conducted which aims to measure the intensity of the relationship between two or more variables and predict the value of $Y$ (dependent variable) over X (independent variable) or is used to determine the direction and influence of the independent variables. The regression equation produced from the research variables is:

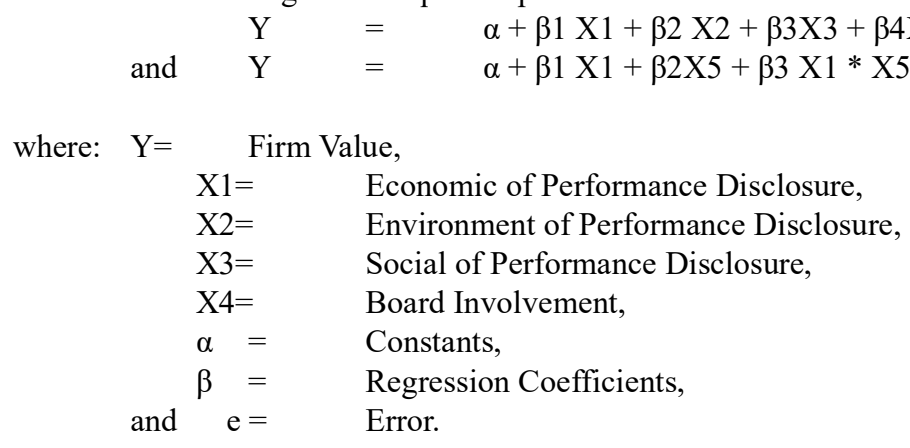

Testing the hypothesis through multiple analysis tests, including (1) the coefficient of determination test, which explains the variation in the influence of independent variables on the dependent variable, measured by the value of R-Square or Adjusted R-Square; (2) simultaneous test, namely testing (model feasibility) which is the initial test to identify a regression model that is estimated to be feasible or not, that is measured if the probF value is smaller than the error ((alpha) 0.05), it can be said that the regression model is feasible, and vice versa; (3) partial test, which is to find out whether the parameters (regression coefficients and constants) are expected to estimate many equations are the right parameters or not or in other words, this parameter can explain the effect of the behavior of independent variables on the dependent variable.

\section{Analysis and Discussion}

The results of the descriptive analysis using SPPS 24 in table 1 shows that companies listed on the Indonesia Stock Exchange have an average company value of 1.3563. Amongst these companies there are companies which have minimum value of 0.24 while the other companies have maximum value of 11.69. The large differences in the company value between those the minimum and maximum that is from 0.24 to 11.69 shows that the value of companies that disclose sustainability between companies varies quite high. While the value of the standard deviation between these companies is 1,80960 .

Furthermore, the results of the classic assumption test as shown in Figure 1 that that probability plots are seen to spread around the diagonal line and still follow the direction of the diagonal line. This means that all research data are normally distributed and the sample in this research is feasible for further research. The results of multicollinearity and heteroscedasticity tests as shown in Table 2 and Figure 2 show that there is no multicollinearity and heteroscedasticity. This is indicated by the VIF values $<10.00$ and Tolerance $>0.10$ and the 
variance points are spread randomly located above and below the number 0 on the $\mathrm{Y}$ axis and do not form a specific pattern. The classic assumption test results for autocorrelation as in Table 3, which shows that the value of DurbinWatson (DW count) of 0.857 . The $\mathrm{dU}$ table value is 1,600 and $4-\mathrm{dU}$ is 2,400 , so that it is obtained (dU $<\mathrm{DW}<4-$ $\mathrm{dU})$. The DW is between $\mathrm{dU}$ and 4-dU, so this means there is no autocorrelation.

The results of the hypothesis test are as follows in table 4, it is known that all independent variables that are significant to Corporate Values, namely Economic, Environment, and Social of Performance Disclosure, has value of 0,000 each.

Table 5

Coefficient Of Determination

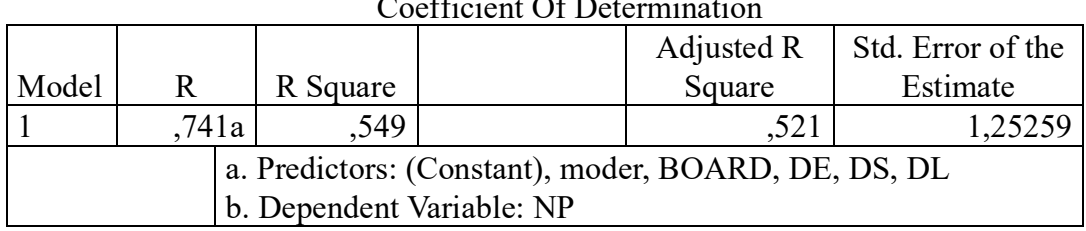

From table 5 above, the results of testing the coefficient of determination indicate that the level of influence of the independent variable on the independent variable, namely DE, DS, DL which is moderated by the board in this equation is equal to $52.1 \%$; the remaining $47.9 \%$ is due to other factors not included in the regression model.

The results of the test for the first hypothesis until the sixth hypothesis based on table 3 above, are as follows:

- H1 with significant level of $0.000<$ of 0.05 , since the alternative hypothesis can be accepted, $\mathrm{H} 0$ is rejected, which means that the Economic Performance Disclosure has significant but negative effect towards the company value.

- H2 with significant level of $0,000<0.05$, thus the alternative hypothesis can be accepted, H0 is rejected, which means that the Environment Performance Disclosure has significant but negative effect towards the company value.

- H3 with significant level of $0.000<$ of 0.05 , thus the alternative hypothesis can be accepted, H0 is rejected, which means that the Social Performance Disclosure has a significant but negative effect towards the company value.

- H4 the value of coefficient determination (R2) is equal to $52.1 \%$, meaning that the presence of board involvement will be able to strengthen the relationship between the Economic Performance Disclosure and the company value.

- H5 the value of coefficient determination (R2) is equal to $52.1 \%$, meaning that the presence of board involvement will be able to strengthen the relationship between the Environment Performance Disclosure and the company value.

- H6 determination coefficient value (R2) is equal to $52.1 \%$, which means that the presence of board involvement will strengthen the influence of Social Performance Disclosure on firm value.

The Discussion of the Result of the Research

- The disclosures of (1) economic performance includes market presence, indirect economic impacts, procurement practices, anti-corruption, and anti-competitive behavior; (2) environment performance includes material, energy, water, biodiversity, emissions, waste water and waste, environmental assessment, suppliers; (3) social performance includes -among others- the relationship of management labor, and occupational health and safety, are still voluntary, so that not all companies take the initiative to disclose it. This is because the implementation of these disclosures requires considerable costs, causing the company's reluctance to implement them. Based on the results of the research, the disclosures have significant but negative effect, which means that the disclosure of economic performance affects the value of the company, but is negative in the three-term. This shows that the costs spent for the work is still greater than its impact towards the positive value of the company.

- In line with the previous research, this research showed that the board involvement can moderate the role of economics, environment, and social performance disclosure on the company performance (Shamil et al. 2014). The board is an important moderator in relation to the company's policy. Thus the Board can strengthen the disclosure of economic performance that is expected to increase the value of the company. The results of the research on the Board involvement, among others, can be seen from the intensity of their attendance at the meetings with average around $89.91 \%$ in each year. 


\section{Conclusion, Limitations, Implications, and Suggestions}

The results of the research based on the discussion as stated in point 4 above, can generate the conclusion that the sustainability disclosures that include economic, environment, and social of performance disclosure have significant but negative effect on firm value. The negative results are due to the costs spent by the company in the context of sustainability disclosures that require considerable costs so that they still cannot influence the company's value positively. Furthermore, the results of the research indicate that board involvement can moderate all sustainability disclosures (economic, environment and social of performance disclosure) towards the firm value. The board has the power and important role as well in taking the best strategic steps for the company (Rakesh and Sheeba 2018), including increasing the disclosure of economic, environmental and social performance which is ultimately expected to increase the value of the company.

The limitation in this research is that the period of the data collecting process covered up only three years (2015, 2016 and 2017). Because the Sustainability Reporting was still voluntary, there were still not too many companies listed on the Stock Exchange of Indonesia compiled the Sustainability Reporting. The results of a research in sufficient time is needed to see the effects of disclosures in Sustainability Reporting. Besides, the research only used 87 samples so that it could not describe the influence of economic, environmental and social disclosures towards the overall value of the company.

The choice of research periodicity which was quite short ( 3 years) to see the effect of sustainability of disclosure towards the firm value had implications for the results of the research which was not sufficient. This is in line with the results of previous studies, namely that sustainability disclosure has a significant but negative influence on company value, which means that the costs for disclosure of sustainability are higher than the effect on company value (Oshika and Saka 2017). However, the sustainability disclosure, which until now is still voluntary in Indonesia, has caused lack of awareness of the stakeholders, so that at the end it does not have positive effect towards the firm value. The results of these studies contradict some of the results of research outside Indonesia, including the results of research that state that there are significant and positive influences between Sustainability Reports and company values (Laskar and Maji 2016). The results of this research can be used as input for the Indonesian government as a regulator to determine sustainability disclosure as an obligation for companies listed on the Indonesia Stock Exchange in the future.

The research should take the span of more than three years, and the research samples must be added, while the proxy of gender and independence must be added to the board involvement variables. This aims to see whether the gender and independence of the board can further moderate the effect of sustainability disclosure towards the firm value.

\section{References}

Amanpreet Kaur. Sumit Lodhia. 2018. Stakeholder Engagement in Sustainability Accounting and Reporting Accounting. Auditing \& Accountability Journal. Publisher: Emeraldinsight.

Elkington, J. 1997. Cannibals with Forks: The triple bottom line of 21st century The triple bottom line of 21st century. England: Capstone Publishing Ltd, Oxford.

Freeman, R. E. McVea. 1984. Strategic Management: A Stakeholder Approach. Boston: Pitman.

Gray, R., Owen, D,. Adams, C. (1996), Accounting and Accountability: Changes and Challenges in Corporate Social and Environmental Reporting". Hemel Hempstead: Prentice Hall.

Gunawan. Abadi. 2010. Content Analysis Method: A Proposed Scoring For Quantitative and Qualitative Disclosures, Handbook of Research Methods in CSR. Publisher by Emeraldinsight.

Government Regulations such as Law Number 40 year 2007 about the Limited Liability Company (Ltd).

Ghozali et al. 2013. Multivariate Analysis and Econometrics Theory, Concepts, and Applications with EViews. Semarang: Publisher: University of Diponegoro.

GRI. (2013). Sustainability Reporting Guidelines . Global Reporting Initiative.

Krippendorff. 2007. Testing the Reliability of Content Analysis Data: What is Involve and Why.

Kotler. Lee. 2005. Corporate Social Responsibility. Doing the Most Good for Your Company and Your Cause. Published by John Wiley \& Sons, Inc., Hoboken, New Jersey.

Lee-Lee Chong, Hway-Boon Ong. Siow-Hooi Tan. 2018. Corporate Risk-Taking and Performance in Malaysia: 
The Effect of Board Composition, Political Connections and Sustainability Practices. The International Journal of Business in Society. Publisher: Emeraldinsight.

Max B. E. Clarkson. 1995. A Stakeholder Framework for Analyzing and Evaluating Corporate Social Performance. The Academy of Management Review, vol. 20, No. 1 (Jan., 1995), pp. 92-117.

Minna Yu and Ronald Zhao. 2015 Sustainability and Firm Valuation: An International Investigation. International Journal of Accounting and Information Management. Vol. 23 No. 3, pp. 289-307. Publisher: Emeraldinsight.

Mohamed M. Shamil, Junaid M. Shaikh, Poh-Ling Ho. Anbalagan Krishnan. 2014. The influence of Board Characteristics on Sustainability Reporting. The Journal of Asian Review of Accounting, vol. 22 No. 2,2014 pp. 78-9. Publisher: Emeraldinsight.

Nayana Chandani Swarnapali Rathnayaka Mudiyanselage. 2018. Board Involvement in Corporate Sustainability Reporting: Evidence from Sri Lanka. The Journal of Corporate Governance: The International Journal of Business in Society. Publisher: Emeraldinsight.

Najul Laskar. Santi Gopal Maji. 2016. Corporate Sustainability Reporting Practices in India: myth or reality?. Social Responsibility Journal, vol. 124 2016, pp. 625-641. Publisher: Emeraldinsight.

Oshika and Saka. 2017. Sustainability KPIs for Integrated Reporting. Social Responsibility Journal, vol. 13 No. 3 2017, pp. 625-642. Publisher: Emeraldinsight.

Rakesh Kumar Mishra, Sheeba Kapil. 2018 "Effect of board characteristics on firm value: evidence from India", South Asian Journal of Business Studies, Publisher: Emeraldinsight.

Report on Inspection of Ernst \& Young LLP. 2012 (Headquartered in New York, New York)

Robert Kristaung, Yvonne. 2018. Research Methodology, Business and Accounting. Jakarta: Dian Rakyat.

Shernaz Bodhanwala. Ruzbeh Bodhanwala. 2018. Does corporate sustainability impact firm profitability? Evidence from India. The Journal of Management Decision. doi 10.1108/MD-04-2017-0381. Publisher: Emeraldinsight.

Sugiyono. 2014. Quantitative Research Methods, Qualitative and R\&D. Bandung: Alfabeta

Shocker, A.D. Sethi,S.P.,1974, “An Approach to Incorporating Social Preferences in Developing Corporate Action Strategies". In Sethie,S.P (ed) The Unstable Ground: Corporate Social Policy in a Dynamic Society, Los Angeles: Melville Publishing Company, pp.67-80

Thomas Donaldson. Lee E. Preston. 1995. The Stakeholder Theory of the Corporation: Concepts, Evidence, and Implications Author. Source: The Academy of Management Review,vol. 20, No. 1 (Jan., 1995), pp. 65-91. Published by: Academy of Management.

Table 1

Descriptive Statistics

\begin{tabular}{|c|c|c|c|c|c|}
\hline & $\mathrm{N}$ & Minimum & Maximum & Mean & Std. Deviation \\
\hline DS & 87 & 15,50 & 51,00 & 31,7241 & 7,04585 \\
\hline DE & 87 &, 00 & 25,00 & 15,1092 & 5,15088 \\
\hline DL & 87 &, 00 & 38,50 & 21,5115 & 8,07414 \\
\hline NP & 87 &, 24 & 11,69 & 1,3563 & 1,80960 \\
\hline BOARD & 87 & 8,00 & 22,00 & 14,5862 & 3,52912 \\
\hline
\end{tabular}

Table 2

Multicollinearity Test

\begin{tabular}{|l|r|r|r|r|}
\hline \multirow{2}{*}{ Model } & \multicolumn{3}{|c|}{ Unstandardized Coefficients } & Collinearity Statistics \\
\cline { 2 - 5 } & \multicolumn{1}{c|}{ B } & Std. Error & Tolerance & VIF \\
\hline (Constant) & 13,987 & 1,445 & & \\
\hline DS &,- 115 &, 027 &, 503 & 1,989 \\
\hline DE &,- 330 &, 038 &, 468 & 2,139 \\
\hline DL &,- 115 &, 025 &, 453 & 2,210 \\
\hline BOARD &,- 277 &, 047 &, 675 & 1,481 \\
\hline moder & $1,571 E-5$ &, 000 &, 184 & 5,433 \\
\hline a. Dependent Variable: NP \\
\hline \multicolumn{5}{|l}{} \\
\hline
\end{tabular}


Table 3

Autocorrelation Test

\begin{tabular}{|l|c|c|c|c|c|}
\hline \multicolumn{7}{|c|}{ Model Summary $^{\mathbf{b}}$} \\
\hline Model & $\mathrm{R}$ & $\begin{array}{c}\mathrm{R} \\
\text { Square }\end{array}$ & $\begin{array}{c}\text { Adjusted R } \\
\text { Square }\end{array}$ & $\begin{array}{l}\text { Std. Error of } \\
\text { the Estimate }\end{array}$ & $\begin{array}{c}\text { Durbin- } \\
\text { Watson }\end{array}$ \\
\hline 1 &, $741^{\mathrm{a}}$ &, 549 &, 521 & 1,25259 &, 857 \\
\hline $\begin{array}{l}\text { a. Predictors: (Constant), moder, BOARD, DE, DS, DL } \\
\text { b. Dependent Variable: NP }\end{array}$ \\
\hline
\end{tabular}

Table 4

Hypothesis Test Results

\begin{tabular}{|c|c|c|c|c|c|c|}
\hline \multirow{2}{*}{\multicolumn{2}{|c|}{ Model }} & \multicolumn{2}{|c|}{ Unstandardized Coefficients } & \multirow{2}{*}{$\begin{array}{c}\text { Standardized } \\
\text { Coefficients }\end{array}$} & \multirow[b]{2}{*}{$\mathrm{t}$} & \multirow[b]{2}{*}{ Sig. } \\
\hline & & $B$ & Std. Error & & & \\
\hline \multirow[t]{6}{*}{1} & (Constant) & 13,987 & 1,445 & & 9,679 & .000 \\
\hline & DS &,- 115 &, 027 &,- 447 & $-4,247$ & 000 \\
\hline & $\mathrm{DE}$ & -330 &, 038 &,- 938 & $-8,596$ & .000 \\
\hline & $\mathrm{DL}$ &,- 115 &, 025 &,- 513 & $-4,621$ & .000 \\
\hline & BOARD &,- 277 &, 047 &,- 541 & $-5,956$ & 000 \\
\hline & moder & $1,571 \mathrm{E}-5$ &, 000 & 1,035 & 5,951 & 000 \\
\hline
\end{tabular}

a. Dependent Variable: NP

Figure 1

Normal Probability Plot

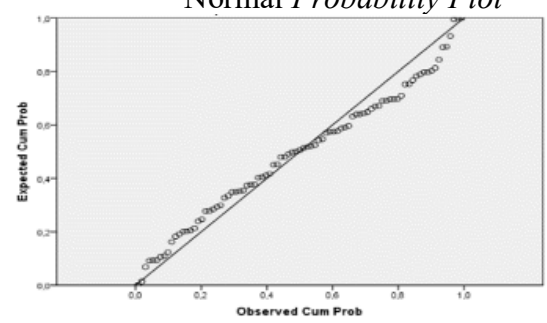

Figure 2

heteroscedasticity test

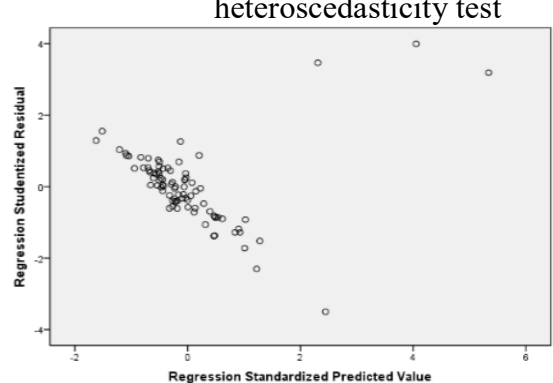

